\title{
Quantification of Tamsulosin Hydrochloride and Solifenacin Succinate by Discriminative Derivative Synchronous Emission Spectroscopy
}

\author{
Tamsulosin Hidroklorür ve Solifenasin Süksinatın Senkronize Türev \\ Emisyon Spektrometrisi Yöntemiyle Eşzamanlı Miktar Tayinleri
}

\author{
(D) Swathi NARAPARAJU*, (D) Pani Kumar D. ANUMOLU², (D) Sunitha GURRALA², (D) Rajeshwari GALENNAGARI² \\ 'Gokaraju Rangaraju, College of Pharmacy, Department of Pharmaceutical Chemistry, Hyderabad, India \\ ${ }^{2}$ Gokaraju Rangaraju, College of Pharmacy, Department of Pharmaceutical Analysis \& Quality Assurance, Hyderabad, India
}

\begin{abstract}
Objectives: The present study was undertaken with the objective to develop and validate a simple spectrofluorimetric method for the simultaneous quantification of tamsulosin hydrochloride and solifenacin succinate.

Materials and Methods: First-derivative synchronous spectrofluorimetry was attempted for the simultaneous quantification of the analytes. Tamsulosin hydrochloride was quantified at a wavelength of $322 \mathrm{~nm}$ (zero-crossing wavelength point of solifenacin succinate) and solifenacin succinate was measured at $570 \mathrm{~nm}$ (zero-crossing wavelength point of tamsulosin hydrochloride).

Results: Calibration plots were constructed over the concentration range of $2-10 \mu \mathrm{g} / \mathrm{mL}$ for tamsulosin hydrochloride and $30-150 \mu \mathrm{g} / \mathrm{mL}$ for solifenacin succinate. The method gave satisfactory results when it is validated for linearity, specificity, accuracy, precision, LOD and LOQ as per the ICH guidelines. The assay values in the commercial formulation were found to be in the percentage range of 95.0 for tamsulosin hydrochloride and 103.5 for solifenacin succinate by the proposed method. These results were well in agreement with their label claim.
\end{abstract}

Conclusion: The proposed synchronous analytical method can be employed for routine quality control analysis of tamsulosin hydrochloride/ solifenacin succinate in tablet dose forms.

Key words: Tamsulosin hydrochloride, solifenacin succinate, synchronous spectrofluorimetry, method validation

Öz

Amaç: Bu çalışmanın amacı tamsulosin hidroklorür ve solifenasin süksinatın aynı anda miktar tayininin yapılabilmesi için basit bir senkronize spektroflorimetri yöntemi geliştirmek ve valide etmektir.

Gereç ve Yöntemler: Bahsedilen analitlerin aynı anda miktar tayinlerinin yapılabilmesi için birinci türev senkronize spektroflorimetri yöntemi kullanılmıştır. Tamsulosin hidroklorür $322 \mathrm{~nm}$ de ölçüm yapılarak (bu dalga boyu solifenasin süksinatın sıfır kesim noktasıdır) solifenasin süksinat ise 570 nm de ölçüm yapılarak (bu dalga boyu tamsulosin hidroklorürün sıfır kesim noktasıdır) miktar tayinleri gerçekleștirilmiştir.

Bulgular: Kalibrasyon eğrileri tamsulosin hidroklorür için 2-10 $\mu \mathrm{g} / \mathrm{mL}$, solifenasin süksinat için ise 30-150 $\mu \mathrm{g} / \mathrm{mL}$ konsantrasyon aralığında hazırlanmıştır. Geliştirilen yöntemle; ICH kılavuzlarına göre hesaplanan doğrusallık, seçicilik, doğruluk, kesinlik ve LOD ve LOQ değerleri kullanılarak başarılı sonuçlar elde edilmiștir. Önerilen yöntemle yapılan analiz sonuçları ticari formülasyon içerisinde tamsulosin hidroklorürün \%95.0 solifenasin süksinatın ise \%103.5 oranında bulunduğunu göstermiştir. Bu sonuçlar preparatın üzerinde belirtilen değerler ile iyi bir uygunluk göstermektedir.

Sonuç: Önerilen analitik yöntemin tablet dozaj formlarında tamsulosin hidroklorür ve solifenasin süksinatın rutin kontrol analizlerinde kullanılabileceği anlașılmıştır.

Anahtar kelimeler: Tamsulosin hidroklorür, solifenasin süksinat, senkronize spektroflorimetri, yöntem validasyonu

*Correspondence: E-mail: swa.pharma@gmail.com, Phone: +09849059163 ORCID-ID: orcid.org/0000-0003-1442-6435

Received: 13.04.2017, Accepted: 13.07.2017

-Turk J Pharm Sci, Published by Galenos Publishing House. 


\section{INTRODUCTION}

Tamsulosin hydrochloride (TMH) is chemically 5-[(2R)-2-\{[2(2-ethoxyphenoxy)ethyl] amino\}propyl]-2-methoxybenzene1 -sulfonamide and used as selective antagonist of $\alpha-1 \mathrm{~A}$ adrenergic receptors.' Solifenacin succinate (SFS) is chemically butanedioic acid (3R)-1-azabicyclo[2.2.2]octan-3-yl (1S)-1-phenyl-1,2,3,4-tetrahydroisoquinoline-2-carboxylate and used as competitive muscarinic acetylcholine receptor (M3) antagonist. ${ }^{2}$ Vesomni, a marketed combined tablet dose form of these drugs was used in the treatment of lower urinary tract symptoms associated with benign prostatic hyperplasia. ${ }^{3}$ The structures of both TMH and SFS are depicted in Figure 1.

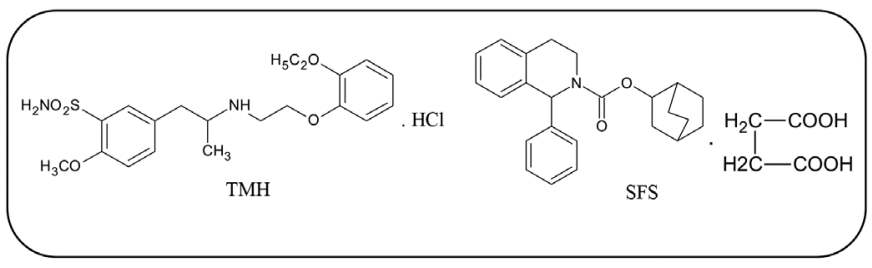

Figure 1. Structures of TMH and SFS

TMH: Tamsulosin hydrochloride, SFS: Solifenacin succinate

A survey of the literature on $\mathrm{TMH}$ revealed several methods, such as visible spectrophotometric methods using Folin reagent, sodium nitroprusside-acetaldehyde ${ }^{4}$ and bromophenol blue ${ }^{5}$, ultraviolet (UV) spectrophotometry ${ }^{6}$, fluorimetry using a sodium dodecyl sulphate micellar system ${ }^{7}$ and methanol ${ }^{8}$. The methods reported for SFS were mainly based on liquid chromatography coupled with tandem mass spectrometry (LC-MS/MS) and UV spectrophotometry. ${ }^{9.10}$ Some spectrophotometric methods using alkaline potassium permanganate, formation of ternary complex with copper (II)/eosin, ammonium molybdate in ammonium thiocyanate and ion-pair complex formation with Bromocresol green"1 have also been described for the analysis of SFS. Spectrophotometric methods are considered to be inappropriate for simultaneous analysis of drugs in multicomponent dose forms due to lack of specificity.

To the best of our knowledge, no method has been reported yet for simultaneous quantification of $\mathrm{TMH}$ and SFS, except reverse-phase high-performance LC (RP-HPLC).12 However, chromatographic methods are complex with costly instrumentation, require skilled operators, and expensive solvents limit the application of simultaneous quantification of above the drugs. Spectrofluorimetry has assumed a special status in drug analysis due to its greater sensitivity and specificity than spectrophotometry using two wave-lengths, excitation, and emission. In accustomed fluorescence, an emission spectrum is attained by scanning the monochromator of emission at various wavelengths $\left(\lambda_{\mathrm{em}}\right)$, at an appropriate excitation wavelength $\left(\lambda_{\text {ex }}\right)$, but in synchronous fluorescence scans both monochromators vary simultaneously. When accustomed spectra are over-lapped, the synchronous technique is used to reduce the extent of overlapping. Derivative spectrofluorimetry is a powerful approach for the resolution of analytes when an analytical peak is overlapped by a large peak of another analyte, particularly in multi-component analysis. ${ }^{13-21}$ The development of a suitable method for simultaneous analysis of TMH and SFS is a challenge because the drugs are present in the ratio of 1:15 in tablet form. If SFS is diluted, the quantification of second drug (TMH) analysis may become difficult. Therefore, simultaneous quantification of TMH and SFS was attempted. A first-derivative synchronous spectrofluorimetric method has been developed based on their native fluorescence and validated as per current International Conference on Harmonization (ICH) guidelines. ${ }^{22}$ The emission spectra of TMH and SFS were overlapped hence it was difficult to analyze and quantify their contents by conventional fluorimetry. This overlap needed to be endeavored by copacetic modification, so a first-derivative synchronous spectrofluorimetric method was contemplated.

\section{MATERIALS AND METHODS}

\section{Chemicals and reagents}

All chemicals and reagents used in the present investigation were of analytical grade. TMH and SFS gift samples were provided by Orchid Pharma Ltd, Chennai, India and the marketed tablet dosage form, Vesomni was procured from local pharmacy.

\section{Instrumentation}

The fluorescence spectra and measurements were recorded using a Shimadzu (Japan) RF-5301 PC spectrofluorimeter equipped with 150-Watt Xenon arc lamp, quartz cell $(1 \mathrm{~cm})$ and connected to RFPC software. The instrument was operated both at low and high sensitivity with excitation and emission slit width set at $5 \mathrm{~nm}$.

\section{Preparation of standard stock solutions}

A stock solution containing $1000 \mu \mathrm{g} / \mathrm{mL}$ of drug was prepared by dissolving $10 \mathrm{mg}$ of TMH/ SFS in $10 \mathrm{~mL}$ of distilled water separately. A 1-mL aliquot of stock solution was diluted up to 10 $\mathrm{mL}$ with distilled water to attain an end concentration $100 \mu \mathrm{g} /$ $\mathrm{mL}$ of each drug.

\section{Analytical method development}

\section{Scanning of drugs by conventional-spectrofluorimetry}

TMH or SFS $(100 \mu \mathrm{g} / \mathrm{mL})$ was diluted to $10 \mathrm{~mL}$ with distilled water to attain an end concentration of $10 \mu \mathrm{g} / \mathrm{mL}$. Spectrofluorimetry mode was used for the scanning of the sample against distilled water to obtain the excitation and emission wavelengths, the anon excitation wavelength was fixed, and solutions were further scanned to obtain the emission spectra. TMH exhibited inveterate fluorescence at emission wavelength $328 \mathrm{~nm}$ after excitation at $292 \mathrm{~nm}$, similarly SFS exhibited fluorescence at emission wavelength $294 \mathrm{~nm}$ after excitation at $256 \mathrm{~nm}$ in distilled water. The emission and excitation spectra of TMH and SFS are shown Figure 2 and 3. Though the excitation and emission wavelengths were disparate for both the drugs, and although the fluorescence spectra exhibited protruding intensity, conventional spectrofluorimetry does not permit the simultaneous estimation of both drugs. 


\section{Synchronous fluorescence spectra}

An attempt was made to attain synchronous spectra of TMH and SFS by maintaining a constant interval of $50 \mathrm{~nm}$ between the emission and excitation wavelengths (Figure 4). There was a large overlap of the spectra of TMH and SFS, hence synchronous spectrofluorimetry was found to be inappropriate. This overlap needed to be endeavored by copacetic modification, so first-derivative synchronous spectrofluorimetric method was contemplated.

\section{First derivative synchronous spectrofluorimetry}

The synchronous zero-order emission spectra were transformed into consonant first-order spectra in the range of

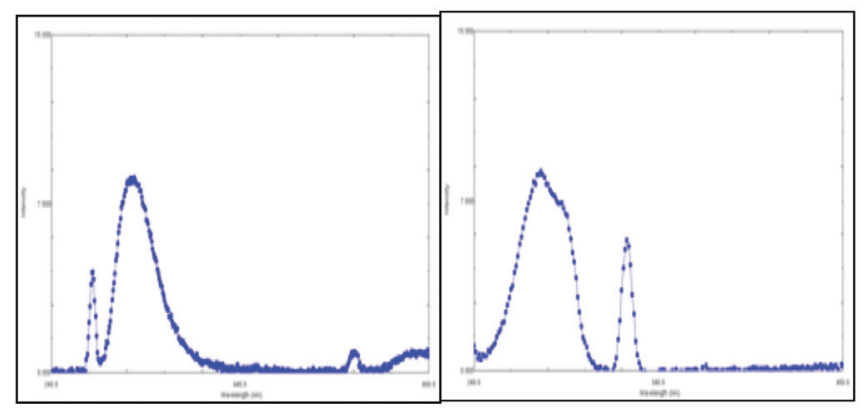

Figure 2. Emission (328 nm) and excitation (292 nm) spectra of TMH (10 $\mu \mathrm{g} / \mathrm{mL}$ ) in distilled water

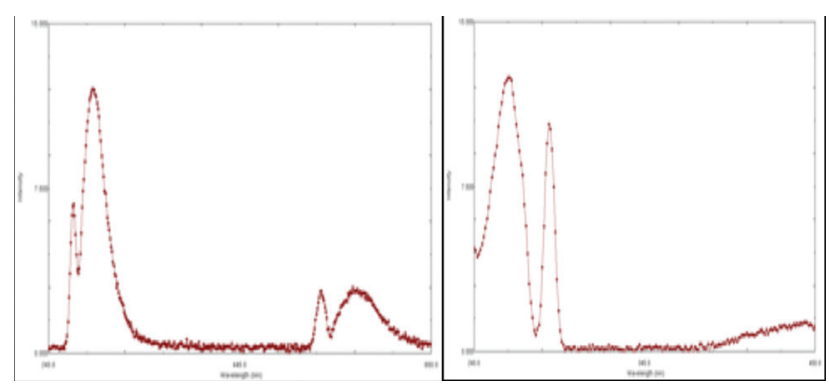

Figure 3. Emission (294 nm) and excitation (256 nm) spectra of SFS (10 $\mu \mathrm{g} / \mathrm{mL}$ ) in distilled water

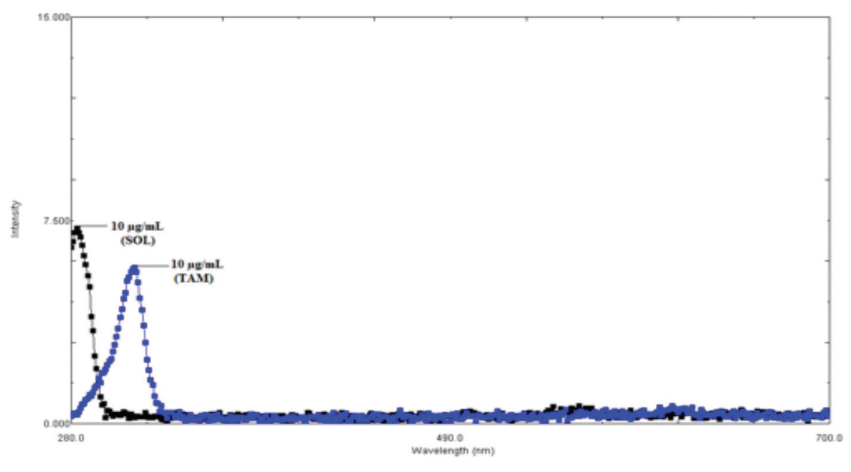

Figure 4. Zero-order synchronous overlaid emission spectra of TMH (10 $\mu \mathrm{g} / \mathrm{mL})$ and SFS $(10 \mu \mathrm{g} / \mathrm{mL})$ in distilled water

TMH: Tamsulosin hydrochloride
350-700 $\mathrm{nm}$. Zero crossing criteria can be used for estimations that are proportional to the concentrations of TMH and SFS.

\section{Analytical method validation}

The method was validated for linearity, specificity, accuracy, precision (both intra and inter-day), limit of detection (LOD), and limit of quantification (LOQ) as per the ICH guidelines to prove that the analytical method could be useful for the quality control of both drugs.

\section{Linearity}

The standard concentrations of TMH $(2-10 \mu \mathrm{g} / \mathrm{mL})$ and SFS (30$150 \mu \mathrm{g} / \mathrm{mL}$ ) were quantified using first-derivative synchronous spectrofluorimetry, anon fluorescence intensities were recorded and a calibration curve was contrived by plotting the analyte intensities paradoxical to the drug concentrations.

\section{Specificity}

The method specificity was assessed by comparing the spectra obtained from the placebo, commercial formulations, and a synthetic mixture of standard solutions. The synthetic mixture was prepared by adding $0.6 \mathrm{~mL}$ of TMH standard stock solution $(100 \mu \mathrm{g} / \mathrm{mL})$ and $0.9 \mathrm{~mL}$ of SFS standard solution $(1000 \mu \mathrm{g} /$ $\mathrm{mL}$ ) to a $10 \mathrm{~mL}$ volumetric flask, the volume was made up to the mark with distilled water to obtain a final concentration of $6 \mu \mathrm{g} / \mathrm{mL} \mathrm{TMH}$ and $90 \mu \mathrm{g} / \mathrm{mL}$ SFS. Then same concentrations of sample solution were prepared using marketed tablets. The method was applied to analyze blank, synthetic mixture, and formulation solutions in order to check if any components of the formulation could generate a response or a read with an emission band similar to the drugs.

\section{Accuracy}

Acquisition studies were conducted using a standard addition method where the known amount of TMH/SFS was added to the pre-analyzed sample according to 80,100 and $120 \%$ levels of the label claim, and further subjected to the contemplated analytical method, and anon percentage recovery, and relative standard deviation (RSD\%) were calculated for each concentration.

\section{Precision}

The intra-day and inter-day precision of the proposed firstderivative spectrofluorimetric simultaneous method was ascertained by estimating the corresponding response three times on the same day (intra-day precision) and on 3 different days over a period of 1 week (inter-day precision) for three different concentrations of TMH $(2,6$ and $10 \mu \mathrm{g} / \mathrm{mL})$ and SFS (30, 90 and $150 \mu \mathrm{g} / \mathrm{mL}$ ).The results are reported in terms of RSD\%.

\section{$\angle O D$ and $L O Q$}

The LOD and $L O Q$ for the proposed method were performed on samples containing very low concentrations of analyte (TMH and SFS) as per the ICH guidelines and calculated based on the calibration curve.

Assay of TMH and SFS in their fixed dose formulation

Twenty tablets of marketed formulation (Vesomni) were 
accurately weighed and powdered. A quantity of powder equivalent to $0.4 \mathrm{mg}$ of $\mathrm{TMH}$ and $6.0 \mathrm{mg}$ of SFS was dissolved in methanol $(5 \mathrm{~mL})$ and sonicated for $15 \mathrm{~min}$. The flask was shaken and the volume was made up to $10.0 \mathrm{~mL}$ with distilled water. The above solution was filtered through Whatmann filter paper (No.41). From the filtrate, $1.0 \mathrm{~mL}$ was transferred into a volumetric flask and the volume was made up to $10.0 \mathrm{~mL}$ with distilled water to give a solution containing $4 \mu \mathrm{g} / \mathrm{mL}$ of $\mathrm{TMH}$ and $60 \mu \mathrm{g} / \mathrm{mL}$ of SFS. This solution was analyzed using the proposed method for the simultaneous quantification of $\mathrm{TMH}$ and SFS. The amount of drugs present in the sample solution were determined by substituting derivative responses into the equation of the linear line representing the calibration curves for TMH and SFS, with correction for dilution.

\section{RESULTS AND DISCUSSION}

\section{Analytical method}

Synchronous scanning spectrofluorimetry in alliance with derivative techniques is expedient in the locution of sensitivity, spectral discrimination, and decisive identification of chemical species in multi-component analysis. TMH molecules contain two aromatic rings, namely ethoxy phenyl, methoxy benzene1-sulfonamide and tetrahydroisoquinoline rings, in which greater numbers of $n$ electrons were available to put on view of fluorescence. Different solvent systems were tested in furtherance of the best predicaments, such as the solubility and fluorescence activity of both drugs. TMH and SFS exhibited the indigenous fluorescence at emission wavelength $328 \mathrm{~nm}$ subsequent to excitation at $292 \mathrm{~nm}$ and emission wavelength $294 \mathrm{~nm}$ subsequent to excitation at $256 \mathrm{~nm}$, respectively in distilled water as solvent. The accustomed and synchronous fluorescence spectra of these drugs overlapped substantially, indicating that these methods did not permit the simultaneous determination of both drugs due to this overlap problem, which was overcome by using first-derivative spectrum (Figure 5), revealing that $\mathrm{TMH}$ gave zero intensity at $570 \mathrm{~nm}$, whereas SFS gave a significant derivative response, likewise, SFS gave zero intensity at $322 \mathrm{~nm}$, but $\mathrm{TMH}$ gave a significant derivative response. Therefore, 322 and $570 \mathrm{~nm}$ were elected for the determination of TMH and SFS, respectively, in the synthetic mixture and tablet forms.

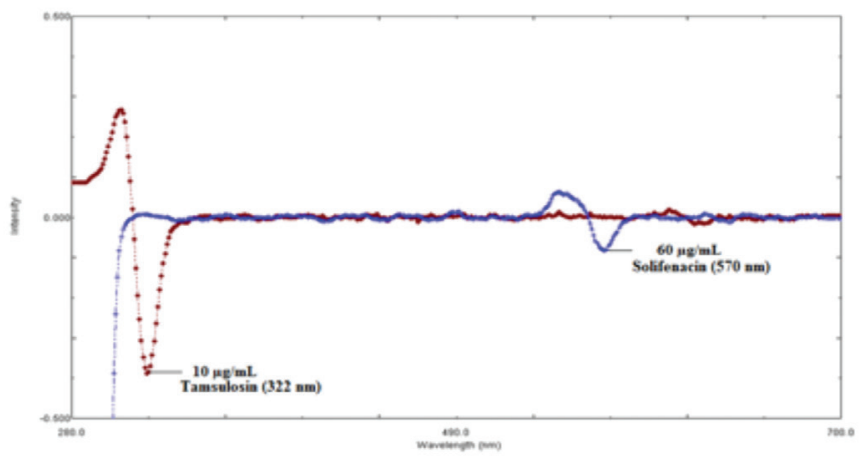

Figure 5. First-order synchronous overlaid emission spectra of TMH (10 $\mu \mathrm{g} / \mathrm{mL})$ and SFS $(60 \mu \mathrm{g} / \mathrm{mL})$ in distilled water

\section{Analytical method validation}

\section{Linearity}

The calibration curve for TMH and SFS was recorded at 322 and $570 \mathrm{~nm}$, respectively. The linearity was evaluated by the least square regression method. The regression analysis of the calibration curves is shown in Figures 6 and 7 . The responses for $\mathrm{TMH}$ at $322 \mathrm{~nm}$ were found to be linear in the concentration range of $2-10 \mu \mathrm{g} / \mathrm{mL}$ with a correlation co-efficient $\left(r^{2}\right)$ value of 0.9996. Similarly, the responses for SFS at $570 \mathrm{~nm}$ were linear in the concentration range of $30-150 \mu \mathrm{g} / \mathrm{mL}$ with a correlation coefficient $\left(r^{2}\right)$ value of 0.9992 . From the Figure 8 , it can be observed that with the increase in $\mathrm{TMH}$ concentration, the derivative response at $322 \mathrm{~nm}$ increased. Similarly, the derivative response for SFS at $570 \mathrm{~nm}$ was proportional to its concentration.

\section{Specificity}

The derivative synchronous spectrum obtained from the commercial formulation solution was compared with the spectrum of synthetic mixture of standard solutions ( $\mathrm{TMH}$ and SFS) and blank. The spectra of both the commercial formulation and the synthetic mixture were found to be similar. Specificity of the method is shown in Figure 9, which revealed that there was no interference from the excipients in the tablets with derivative response of either drug (TMH and SFS) at their respective analytical wavelengths (322 and $570 \mathrm{~nm}$ ). Hence, the method was proved to be specific.

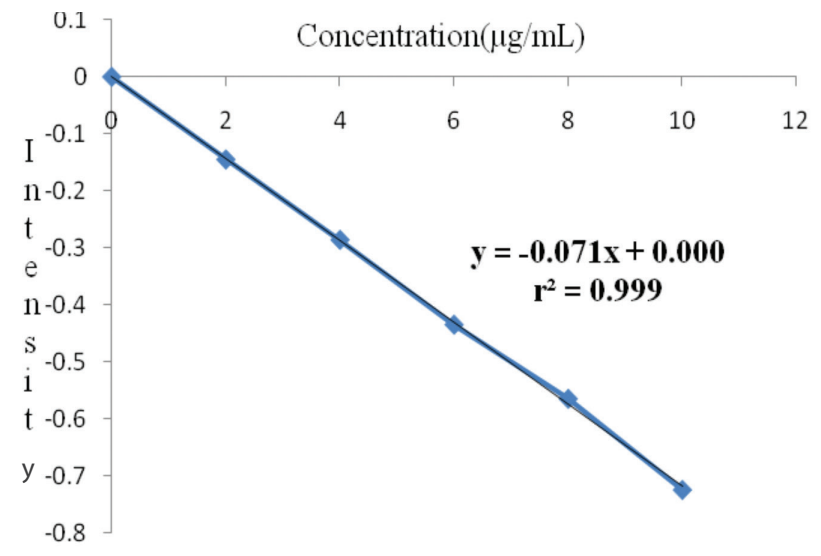

Figure 6. Linearity plot of $\mathrm{TMH}(2-10 \mu \mathrm{g} / \mathrm{mL})$ in distilled water at $322 \mathrm{~nm}$

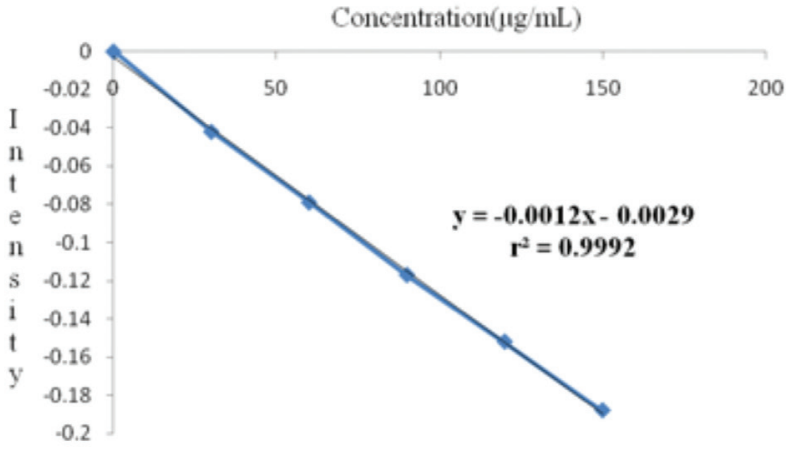

Figure 7. Linearity plot of SFS (30-150 $\mu \mathrm{g} / \mathrm{mL})$ in distilled water at $570 \mathrm{~nm}$ 


\section{Accuracy}

The accuracy of the analytical method was determined using the standard addition method. Three different levels $(80,100$ and $120 \%$ ) of standards were spiked to commercial tablets in triplicate. The mean percentage recoveries and RSD\% values were calculated and reported in Table 1. The percentage recoveries of TMH and SFS were found to be in the range 102.27-113.75 and 97.22-101.0, respectively, which were found to be satisfactory.

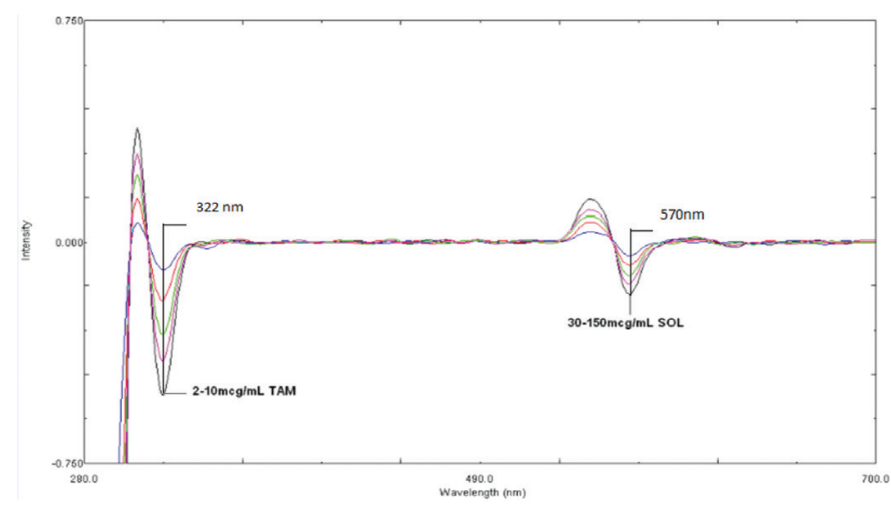

Figure 8. First-derivative linearity spectra of TMH $(2-10 \mu \mathrm{g} / \mathrm{mL})$ and SFS $(30-150 \mu \mathrm{g} / \mathrm{mL})$

\section{Precision}

The repeatability (intra-day precision) and intermediate precision of the method was determined by three concentrations for both TMH (2, 6 and $10 \mu \mathrm{g} / \mathrm{mL})$ and SFS (30, 90 and 150 $\mu \mathrm{g} / \mathrm{mL}$ ). The results are summarized in Table 2 . The RSD\% of repeatability was less than 2.0 for both drugs, indicating good precision of the developed method.

\section{$\angle O D$ and $L O Q$}

From the linearity plot the LOD and LOQ of TMH and SFS were calculated. The LOD and LOQ for TMH was 0.210 and 0.639

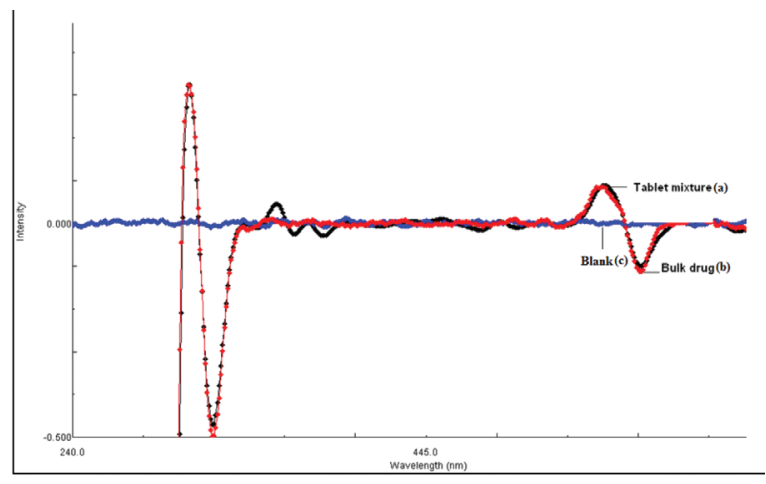

Figure 9. First-order synchronous overlaid spectra of commercial formulation (a), synthetic mixture (b) and blank (c)

\section{Table 1. Accuracy data of the analytical method}

\begin{tabular}{|c|c|c|c|c|c|c|c|}
\hline Analyte & $\begin{array}{l}\text { Recovery level } \\
\%\end{array}$ & $\begin{array}{l}\text { Amount of standard } \\
(\mu \mathrm{g} / \mathrm{mL})\end{array}$ & $\begin{array}{l}\text { Conc of sample spiked } \\
(\mu \mathrm{g} / \mathrm{mL})\end{array}$ & $\begin{array}{l}\text { Total amount } \\
(\mu \mathrm{g} / \mathrm{mL})\end{array}$ & $\begin{array}{l}\text { Amount recovery } \\
(A M \pm S D)(\mu g / m L) \\
(n=3)\end{array}$ & $\%$ Recovery & RSD\% \\
\hline \multirow{3}{*}{ TMH } & 80 & 0.4 & 0.32 & 0.72 & $0.75 \pm 0.012$ & 104.16 & 1.60 \\
\hline & 100 & 0.4 & 0.4 & 0.8 & $0.91 \pm 0.007$ & 113.75 & 0.76 \\
\hline & 120 & 0.4 & 0.48 & 0.88 & $0.90 \pm 0.011$ & 102.27 & 1.20 \\
\hline \multirow{3}{*}{ SFS } & 80 & 6.0 & 4.8 & 10.8 & $10.52 \pm 0.078$ & 97.22 & 0.74 \\
\hline & 100 & 6.0 & 6.0 & 12.0 & $12.12 \pm 0.026$ & 101.0 & 0.21 \\
\hline & 120 & 6.0 & 7.2 & 13.2 & $13.00 \pm 0.054$ & 98.48 & 0.41 \\
\hline
\end{tabular}

SFS: Solifenacin succinate, TMH: Tamsulosin hydrochloride, RSD: Relative standard deviation

\section{Table 2. Data for precision of the analytical method}

\begin{tabular}{|c|c|c|c|c|c|}
\hline \multirow[b]{2}{*}{ Drug } & \multirow[b]{2}{*}{ Concentration $(\mu \mathrm{g} / \mathrm{mL})$} & \multicolumn{2}{|l|}{ Intra-day precision } & \multicolumn{2}{|l|}{ Inter-day precision } \\
\hline & & $\begin{array}{l}\text { Concentration estimated }(\mu \mathrm{g} / \mathrm{mL}) \\
(A M \pm S D)(n=3)\end{array}$ & RSD $\%$ & $\begin{array}{l}\text { Concentration estimated }(\mu \mathrm{g} / \mathrm{mL}) \\
(A M \pm S D)(n=3)\end{array}$ & RSD $\%$ \\
\hline \multirow{3}{*}{ TMH } & 2 & $2.01 \pm 0.005$ & 0.24 & $2.12 \pm 0.004$ & 0.18 \\
\hline & 6 & $6.21 \pm 0.012$ & 0.19 & $6.05 \pm 0.022$ & 0.36 \\
\hline & 10 & $10.07 \pm 0.025$ & 0.24 & $10.05 \pm 0.034$ & 0.33 \\
\hline \multirow{3}{*}{ SFS } & 30 & $31.28 \pm 0.064$ & 0.20 & $31.02 \pm 0.046$ & 0.40 \\
\hline & 90 & $91.28 \pm 0.029$ & 0.03 & $90.15 \pm 0.084$ & 0.09 \\
\hline & 150 & $148.08 \pm 0.226$ & 0.15 & $150.22 \pm 0.152$ & 0.10 \\
\hline
\end{tabular}

SFS: Solifenacin succinate, TMH: Tamsulosin hydrochloride, RSD: Relative standard deviation 
Table 3. System suitability parameters of TMH and SFS

\begin{tabular}{|c|c|c|}
\hline Parameter & TMH & SFS \\
\hline $\begin{array}{l}\text { Emission } \\
\text { wavelength }(\mathrm{nm})\end{array}$ & 322 & 570 \\
\hline $\begin{array}{l}\text { Beer's law limit } \\
(\mu \mathrm{g} / \mathrm{mL})\end{array}$ & $2-10$ & $30-150$ \\
\hline Slope (m) & -0.0720 & -0.0010 \\
\hline Intercept (c) & 0.0002 & -0.0030 \\
\hline $\begin{array}{l}\text { Correlation } \\
\text { coefficient }\left(r^{2}\right)\end{array}$ & 0.9992 & 0.9996 \\
\hline $\mathrm{LOD}(\mu \mathrm{g} / \mathrm{mL})$ & 0.210 & 2.64 \\
\hline $\mathrm{LOQ}(\mu \mathrm{g} / \mathrm{mL})$ & 0.639 & 8.0 \\
\hline $\begin{array}{l}\text { Regression } \\
\text { equation }\end{array}$ & $y=-0.07196 x+0.00024$ & $y=-0.00125 x-0.00290$ \\
\hline
\end{tabular}

SFS: Solifenacin succinate, TMH: Tamsulosin hydrochloride, LOD: Limit of detection, LOQ: Limit of quantification

Table 4. Assay data of TMH and SFS in marketed formulation

\begin{tabular}{llllll} 
Formulation & Drug & $\begin{array}{l}\text { Label } \\
\text { claim } \\
(\mathrm{mg})\end{array}$ & $\begin{array}{l}\text { Amount found }(\mathrm{mg}) \\
(\mathrm{AM} \pm \mathrm{SD})(\mathrm{n}=3)\end{array}$ & \% Assay & RSD\% \\
\hline \multirow{2}{*}{ Vesomni } & $\mathrm{TMH}$ & 0.4 & $0.38 \pm 0.006$ & 95.0 & 1.57 \\
\cline { 2 - 6 } & $\mathrm{SFS}$ & 6 & $6.21 \pm 0.024$ & 103.5 & 0.38 \\
\hline
\end{tabular}

RSD: Relative standard deviation, SFS: Solifenacin succinate, TMH: Tamsulosin hydrochloride

$\mu \mathrm{g} / \mathrm{mL}$ and SFS was found to be 2.640 and $8.0 \mu \mathrm{g} / \mathrm{mL}$. The summary of the system suitability parameters is represented in Table 3. The results obtained from validation evidenced that the proposed method was scientifically sound.

\section{Assay of drugs from commercial tablets}

The accuracy of the proposed method was evaluated through the assay of commercially available tablets (VESOMNI) containing $0.4 \mathrm{mg}$ of TMH and $6 \mathrm{mg}$ of SFS. The results obtained were compared with the corresponding labeled amounts and reported in Table 4. The amount of TMH and SFS in formulation was found to be $0.38 \pm 0.006$ and $6.21 \pm 0.024 \mathrm{mg}$, respectively. The percentage assay in the commercial formulations was found to be 95.0 for TMH and 103.5 for SFS by the proposed method. The RSD\% for formulation was less than 2, which indicates the accuracy of the proposed method.

\section{CONCLUSION}

A simple and rapid first derivative synchronous spectrofluorimetric method for the simultaneous quantification of TMH and SFS was developed and validated as per the $\mathrm{ICH}$ guidelines. The results of validation studies denoted the immense scope of sensitivity, accuracy, precision, and system suitability of the analytical method. The proposed method was successfully adopted for the assay of TMH and SFS and the results were found to be in good agreement with their respective label claims, which suggested that there was no interference of formulation excipients in the estimation. The contemplated spectrofluorimetric method was found to be superior because of its high specificity, spectral discrimination, economic, eco-friendly, and readily available solvent and lack of extraction procedure. These advantages endorse that the developed method can be habitually employed in quality control for simultaneous analysis of TMH and SFS in tablet dose forms.

\section{ACKNOWLEDGEMENTS}

The authors are thankful to Dr. C.V.S. Subrahmanyam, Principal, Gokaraju Rangaraju College of Pharmacy and the Gokaraju Rangaraju Educational Society (GRES) for providing necessary laboratory facilities.

Conflict of Interest: No conflict of interest was declared by the authors.

\section{REFERENCES}

1. Takenaka T, Fujikura T, Honda K, Asano M, Niigata K. Discovery and development of tamsulosin hydrochloride, a new alpha 1-adrenergic antagonist. Yukugaku Zasshi. 1995;115:773-789.

2. Ohtake A, Saitoh C, Yuyama H, Ukai M, Okutsu H, Noguchi Y, Hatanaka T, Suzuki M, Sato S, Sasamata M, Miyata K. Pharmacological characterization of a new antimuscarinic agent, solifenacin succinate, in comparison with other antimuscarinic agents. Biol Pharm Bull. 2007;30:54-58.

3. Dimitropoulos K, Gravas S. Solifenacin/tamsulosin fixed-dose combination therapy to treat lower urinary tract symptoms in patients with benign prostatic hyperplasia. Drug Des Devel Ther. 2015;9:17071716.

4. Raghubabu K, Swarup Shanti L, Kalyanaramu B, Rao MN, Ramdas C. Simple and inexpensive methods development for the estimation of tamsulosin hydrochloride as a single component from its solid dosage forms by Visible spectrophotometry. Int J Pharm Biol Sci. 2012;2:12-19.

5. Shrivastava A, Saxena P, Gupta VB. Spectrophotometric estimation of tamsulosin hydrochloride by acid-dye method. Pharm Methods. 2011;2:53-60.

6. Thimmaraju MK, Rao V, Hemanth K, Siddartha K. Determination of tamsulosin in bulk and pharmaceutical dosage forms by UV spectrophotometric method. J Chem Pharm Res. 2011;3:762-767.

7. Rizka M, Toubara SS, Habibb HI, Mona S, Elshaheda. Stability indicating micelle-enhanced spectrofluorimetric method for determination of tamsulosin hydrochloride in dosage forms. J Adv Chem. 2015;11:35133531.

8. Patel DB, Patel NU, Chaudhari BG. Validated spectrofluorimetric method for the determination of tamsulosin hydrochloride in tablet dosage form. Pelgia Research Library. 2011;2:172-175.

9. Puttagunta SB, Shaik RP, Bannoth CK, Challa BSR, Awen BZS. Bioanalytical method for quantification of solifenacin in rat plasma by LC-MS/MS and its application to pharmacokinetic study. J Anal Sci Technol. 2014:5:35.

10. Rakesh B, Bhargavi P, Reddy SR, Kumar AA. UV-Spectrophotometric method development and validation for the quantitative estimation of solifenacin succinate in tablets. Int J Pharm Pharm Sci. 2014;6:190-193. 
11. Seshamamba BSV, Satyanarayana PVV, Sekaran CB. Development and validation of spectrophotometric methods for the quantification of solifenacin succinate application to tablet dosage forms. Int Let. Chem Phy Astr. 2013;15:167-182.

12. Israel DS, Krishnachaitanya K, Sankar DG. RP-HPLC Method for the estimation of tamsulosin and solifenacin in bulk and its dosage forms. Int J Pharm Sci Res. 2013;4:4343-4350.

13. Mark H, Workman J. Chemometrics in Spectroscopy Derivatives in Spectroscopy Update. Spectroscopy. 2003;18:32-37. Available at: http:// alfresco.ubm-us.net/alfresco_images/pharma/2014/08/22/c9fd51ed5973-468c-bfea-14b156c5063d/article-137753.pdf

14. Morelli B. Derivative spectrophotometry in the analysis of mixtures of cefotaxime sodium and cefadroxil monohydrate. J Pharm Biomed Anal. 2003;32:257-267.

15. Patra D, Mishra AK. Recent developments in multi-component synchronous fluorescence scan analysis. Tracc Trends Anal Chem. 2002;21:787-797.

16. Andrade-Eiroa A, De-Armas G, Estela JM, Cerda V. Critical approach to synchronous spectrofluorimetry. Trac Trends Anal Chem. 2010;29:885901.
17. Walash MI, Belal FF, El-Enany NM, El-Maghrabey MH. Synchronous fluorescence spectrofluorimetric method for the simultaneous determination of metoprolol and felodipine in combined pharmaceutical preparation. Chem Cent J. 2011;5:70.

18. El-Wassef DR, El-Sheebiny DT, Abu-El-Enein MA, El-Ashry SM. Simultaneous determination of labetalol and furosemide by first derivative synchronous spectrofluorimetry. J Fluoresc. 2009;19:817-828.

19. Anumolu PD, Neeli S, Anuganti H, Sathesh BR, Puvvadi S, Subrahmanyam CVS. First Derivative Synchronous Spectrofluorimetric Quantification of Telmisartan/Amlodipine Besylate Combination in Tablets. Dhaka Univ J Pharm Sci. 2013;12:35-40.

20. Anumolu PD, Neeli S, Anuganti H, Ranganatham SBP, Satya SCV. Development of dissolution test method for a telmisartan/amlodipine besylate combination using synchronous derivative spectrofluorimetry. Braz J Pharm Sci. 2014;50:329-336.

21. Anumolu PD, Gurrala S, Bagirath R, Vani PS, Archana G. Zerocrossing point derivative simultaneous spectrofluorimetric method for quantification of nebivolol hydrochloride and valsartan combination in tablets. Int J Pharma Sci Rev Res. 2014;27:164-168.

22. Q2 (R1), International Conference on Harmonisation, Guideline on Validation of Analytical Procedure: Text and Methodology; 2005. 